\title{
Colour cosmetics consumption among Moroccan women: Examining the Nexus of Attitudes, Religion, and The media
}

\section{Abstract}

This paper examines colour cosmetic consumption of Morrocan women in relation to the influence of attitudes, religion, and the media. With data from 498 women and using the theory of planned behavior, this study shows that attitude and Perceived behavior control (PBC) affect positively consumer intention to buy colour cosmetics. It also shows that intrinsic or personal religiosity does not affect customer intention to purchase cosmetic products while extrinsic religiosity is negatively correlated to the intention to use these products. Besides, the study demonstrates how different types of media influence the respondents' consumption of these products. For example, as respondents spend more time watching TF1- the first national French channel - where a more natural look is displayed, the intention to buy color cosmetics decreases by $41.6 \%$. Concerning the socio-demographic factors, the study shows that older women mainly with high income are more likely to consider color cosmetics consumption. The implications of the study are highlighted in the paper.

Key words: Purchase Intention, Attitude, Media, Religiosity, Perceived behavioral control, colour cosmetics, women

\section{Introduction}

In 2012, colour cosmetics demonstrated 8\% current value growth to reach Dh 727 million in Morocco as female consumers believe that the products are very important (Euromonitor, 2013). For looking younger, beautiful, and attractive, a considerable number of Moroccan 
female consumers wear make-up on a daily basis (Kumar, 2005) and this consumption trend was unaffected by the economic crises (Euromonitor, 2013). However, with the GDP value of Morocco being $0.16 \%$ of the world economy, Moroccan female consumers cannot afford to use premium brands daily and are more comfortable using standard and economy products (Euromonitor, 2013). By definition, color cosmetics are all colorful products that a female consumer wears which are categorized into four types: Eye Make-up such as Eye Shadow, Mascara, and Eyeliner; Facial Make-up such as Blusher, Foundation, and Powder; Lip Products such as Lip Gloss, Lipstick, and Lip Liner; and Nail Products such as Nail Polish, Polish Remover, and Nail Strengthener (Euromonitor, 2013). Generally, color cosmetics are the pervasive element of feminine culture (Coulter, Price \& Feick, 2003; Davies, 2006) while make-up inscribes the attitudes of personality onto the social body (Craik, 1993).

According to Euromonitor's (2013) estimated figures, colour cosmetics is expected to have a Compounded Annual Growth Rate (CAGR)of 7\% for the period forecasted 20122017 with the Mascara and foundation being the highest performer in term of annual growth. Overall, colour cosmetic industry is such an important sector in Morocco. Cash and Cash (1982) found that women get a more positive body image and self-image when wearing make-up compared to when not wearing makeup. It is therefore not surprising that International companies operating in colour cosmetics focus on mass media advertising to promote their values (Cash, 1988). Hence, it will be significantly beneficial both from the academic and managerial perspective to understand the attitudes of Moroccan women to the use of these products, especially as this has not been previously addressed before. According to Akbar (2009), Morocco is becoming more westernized due to the increase exposure to global economy and international media. Therefore, the intention to buy color cosmetics might be affected by the media such as TV, Internet, and magazines. Similarly, it has been shown that religion is another potential factor shaping consumer behavior (Hessini, 1994). 
In fact, many studies have shown that religion and religiosity impact consumer behavior in many areas such as retail supply patronage, decision making, shopping alignment, and perception and advertising signals (Delener, 1994; Siguaw and Simpson, 1997; Fam et al., 2004; Esso and Dibb, 2004). Therefore, it is crucial to understand the impact of religiosity on the intention to buy color cosmetics among these women. Thus, this constitutes the main objective of this study.

\section{Literature Review}

Women, Beauty, and Self-concept

The notion of self-concept and identity has been very fundamental to the discourse of consumer behavior for a long time (Belk, 1988; Elliott, 1997; Banister and Hogg, 2004; Gbadamosi, 2015). The extant literature has strongly linked self-concept to self-esteem (Grubb and Graithwohl, 1967; Rucker, et al., 2011)). Scott (2007) posits that many women suffer from low self-esteem and self-confidence and consequently have an adverse opinion of their personal beauty. Cosmetic products are a quick fix to meet beauty ideals (Miller and Cox, 1982) and mend a low self-esteem. A number of studies have pointed out that women tend to compare themselves to others, especially in the context of beauty. For example, women were found to be more depressed and angry after viewing female models on magazine (Pinhas, 1999). Nowadays social media was shown to have a similar effect, lowering self-esteem and self-confidence (Perloff, 2014). Nevertheless, there has been little research on how cosmetics provide woman with a higher self-esteem and self-confidence, especially in relation to religiosity. Hence, it will be of significant value to examine the specific impacts of these, especially in relation to religiosity as a key consumer behavior phenomenon. 


\section{Motives behind buying color cosmetics}

To have an in-depth understanding of the motives behind buying color cosmetics, the theory of planned behavior (TPB) shown in Figure 1 has been chosen, and it states that there are three factors affecting intention: subjective norm, attitude and perceived behavioral control (PBC) (Ajzen, 1991). This theory is used to justify a wide array of behaviors (Fishbein and Ajzen, 2010). In this study, the theory is used to explain whether subjective norm, attitude and perceived behavioral control influence the intention to buy colour cosmetics.

Place Figure 1 about here

\section{a. Subjective norm}

Subjective norm refers to the pressure that the society exercises on an individual to perform a specific behavior or avoid it (Ajzen, 2002). In other words subjective norms originate from the idea that a person or group of people will approve or disapprove a particular behavior (Ham et al. 2015). Subjective norm is shaped by both Interpersonal influence which involves the influence friends, family, and significant others, while external sources' influence refers to influences by mass media, such as television, magazine, social media (Brown \& Venkatesh, 2005; Arias, 2016; Burchell, Rettie, Patel, 2013). Behavioral intention is indeed directly impacted the subjective norm (Ajzen \& Albarracin, 2007). In particular Venkatesh et al. (2003) show that there is a positive correlation between subjective norms and behavioral intention to buy color cosmetics. Kim and Chung (2011), Souiden and Diagne (2009) supported these findings and showed that there is a positive correlation between subjective norm and the behavioral intention concerning skin care products. A 
number of studies have reported this positive correlation between the two variables. For example, Guthrie et al. (2008) and Vanessa et al. (2010) empirically proved in their research that female customers specifically are affected by the social comparison to increase their attractiveness and expose their unconscious world. This is closely related to the findings of Gbadamosi (2012) about acculturation and Black African women consumption of clothing in the UK. In this research, findings show that these women purchase behavior for clothing are influenced by social factors in two directions. Firstly, their purchase and use of clothing is influenced by their need to affiliate with people in their host cultural system and on the other hand, they still stick to some of their traditional outfits in the foreign cultural environment in order to be able to affiliate with people of their similar cultural orientation who reside in the country during traditional events. In addition, in Sweden, it has been stated that the subjective norm would have a considerable impact on consumers' purchasing behavior when the product bought has a link with fashion and trend (Crespo \& Rodríguez, 2008). Other than media shaping subjective norm, religiosity is also to be considered.

\section{Religiosity}

Religion has been defined as the system of the actions, judgments, cerebral and emotional procedures, which aid individual, overwhelm, prevent, alleviate, or offset anxiety and worry (Labarbera, 1972). It favors a certain basis for people, and makes their lives purer (Peterson and Roy, 1985). Evidence shows a number of religious beliefs that often pattern people's life including consumption activities and to varying degrees, are anti-materialistic - viewing materialism broadly as antithetical to spiritual values (O'Shaughnessy \& O'Shaughnessy, 2002). For example, Islam prohibits overt consumption of luxuries and warns against hoarding: "And let those who hoard gold and silver and do not spend them in 
the way of Allah know that a severe and painful punishment is awaiting them." [At-Tauba:

Religiosity reflects the degree to which beliefs in religious values and ideals are held and practiced by an individual (Delener, 1990). Many studies have shown that religion and religiosity impact consumer behavior in many areas such as retail supply patronage (Siguaw and Simpson, 1997); decision making (Delener, 1994); shopping alignment (Esso and Dibb, 2004), and perception and advertising signals (Fam et al., 2004). For example, studies have shown that people are more encouraged to buy products that are advertised as being promoted by the religious group they are affiliated to (Esso and Dibb, 2004) while a few other perspectives show that religiosity impact people's decision-making process and their choice of products to buy (Delener, 1994; Arli et al., 2016; Casidy, et al., 2016; AlAbdularazak and Gbadamosi, 2017; Gbadamosi, 2018). Specifically, the relationship between religion and color cosmetics has been a big issue for years. The Quran and Suna were clear in forbidding women to show their beauty for strangers except for their husband, father, brother and son. This is emphasized in Surat an -Nour, ayat 31. Hence, one could infer that the Quran forbids women to wear conspicuous make-up in public.

Meanwhile, the CIA world fact book indicate that 99\% of Moroccans are Muslim (2012). However, Morocco is a society influenced by both Muslim tradition and western norms (Hessini, 1994). Hence, by examining these contentions around colour cosmetic consumption, the paper is positioned to extend our knowledge on this subject.

Religion can be described as a set of beliefs and values that direct behavior (Delener, 1994), while religiosity, on the other hand, is defined by the degree to which beliefs in religious values and ideals are held and performed by an individual (Bachleda, Hamelin Benachour, 2014). Allport (1950) posits that the construct of religiosity comprises two dimensions: 
intrinsic religiosity and extrinsic religiosity. For Allport (1950), an extrinsically driven person use religion in a practical way for purpose such as social acceptance (Belku, 2004) while an intrinsically driven person lives his/her religion in mindfulness of the importance of beliefs and dogma. These two dimensions, intrapersonal (cognitive), and interpersonal (behavioral) are measured using nine items adapted from the Religious Commitment Inventory (Worthington et al., 2003). Various researches have emphasized the role of religiosity as a key factor exerting a strong influence on consumer behavior (Veer and Shanker, 2011; Bachleda et al., 2014).

Media and subjective norm

The propensity for media to establish a norm is well established. For example Bessenoff (2006) shows that women exposed to thin-ideal ads are more likely to engage in social comparison and had a higher level of body dissatisfaction, higher level of levels of depression and lowered self-esteem. The media is also playing a very significant role in the globalization process through manipulating emotions and sending messages that have an impact on people's daily life (Kotwal et al, 2008). According to Kulsiri (2012), the exposure of media has been proved to affect positively consumer's purchases behavior. For example, evidence shows that Moroccans are exposed to multiple international channels, internet, and social media (Akbar, 2009). In their research analyzing the TV advertising impact on adolescent purchasing behavior, Kotwal et al (2008), show that girls view TV advertisement with extreme interest and perceive the product exposed as a miracle that would change their lives. 


\section{Social norms Theory}

Social Norms Theory posits that an individual's behavior is influenced by mistaken perceptions of how other members within a particular social group think and act (Berkowitz, 2004). Social Norms Theory was firstly established to understand the problem of binge drinking on American campuses (Haines, 1996). The study uncovered that students who believed that their peers drank more would increase their alcohol consumption to match what they thought their peers did. This research tests the idea that perception of wealth could be correlated to the use of color cosmetic.

It has been argued that Moroccan citizens follow more a liberal western lifestyles than a traditional Arab-Islamic (Gray and Amine, 2002). According to the Interprofessional Center media audience measurement (Ciaumed), Moroccans watches TV 3 hours and 48min a day on the average. In fact, only $51 \%$ of the population watches Moroccan channels (El Khalfi, 2012). $2 \mathrm{M}$ is a public channel that targets low and middle-income residents (Le Journal Hebdo, 2012) and succeeds in attracting more than $20 \%$ of the population. Then, comes AlOULA with $9 \%$ while ASSADYSSA target only $0.5 \%$. On the other hand, TF1, mbc1, Aljazeera, Ikraa attract a large number of audiences rating of $11.3 \%, 15.9 \%, 12 \%$ and $16.5 \%$ respectively. Therefore, TV might have a huge impact on people' self-concept, religiosity and values. With reference to the June, 2012 Internet World Stat, Morocco has been noted the $4^{\text {th }}$ of African countries in terms of number of Facebook users with an estimated number of more than 6 million users (Arbaoul, 2014). For example, the page of Sayidaty, which provides information about fashion to young female audience, and displays a variety of advert for some major cosmetic brand has 2179436 fans. These figures are considerable. 


\section{b. Attitude}

According to Kotler and Armstrong (2018: p173), 'Attitude describes a person's relatively consistent evaluations, feelings, and tendencies toward an object or idea'. The estimation about a product to be good or not is very important for the decision making process. According to Verbecke \&Vackier (2005), a positive attitude towards a behavior makes people more likely to purchase and a negative attitude towards product leads to a decrease in our willingness to buy the product. Marcoux (2000) found that there is a strong correlation between attitude and the intention to buy skin products. Moreover, a strong relationship has been shown between attitude and the intention to buy cosmetics (Sukato \& Elsey, 2009; Kim \& Chung, 2011). Empirical studies in Sweden have shown that the more favorable attitude women have towards color cosmetics, the higher is their intention to buy cosmetics (Nikdavoodi, 2013). This same study also shows that make-up products have proven to increase women attractiveness and help hide any imperfection in their faces. Hence, a positive attitude towards colour cosmetics encourages female consumers to consume different color cosmetic such as eyeliner. As a result, female's intention to buy colour cosmetics is increased and their esthetic need is satisfied (Sukato and Elsey, 2009).

\section{c. Perceived behavioral Control}

Perceived behavioral control (PBC) is the perception of an individual about his ability to perform certain action (Liao et al., 2008). PBC is determined by the total set of control beliefs (Liao et al, 2008). It is often discussed when the behavior studied is not under complete control of the individual (Ajzen, 2002). It describes the perception of the resources needed to perform a specific behavior (Armitage and Conner, 2001) and includes the perceptions about the existence or lack of resources needed to engage in a behavior. 
According to Nash et al. (2006), there is a negative relationship between perceived behavioral control and color cosmetics usage. Therefore, the intention of buying colour cosmetics is reinforced when women have independence in deciding when and where to wear color cosmetics.

\section{d. Intention and Color Cosmetics}

The theory of planned behavior states that the intention is influenced by attitude, subjective norms, and perceived behavior control (Fishbein and Ajzen, 2010).. Consequently, the theory of planned behavior states that the intention towards a specific behavior is very important in measuring and predicting the actual behavior (Fishbein and Ajzen, 2010). Therefore, this study examines the influence of attitude, subjective norms, and perceived behavior control vis-à-vis colour cosmetics consumption in the given context.

\section{Demographics and Colour cosmetics}

In Morocco, the average unit prices in colour cosmetics recorded a marginal upward movement in 2011 driven by the distribution costs and the introduction of highly priced new products (Euromonitor, 2013). However, this same report shows that the largest population in Morocco falls into the middle class which correspond to low income. Therefore, Moroccan women might not be able afford to use premium brands daily and are more comfortable with using standard and economy products (Euromonitor, 2013). Therefore, income might be a very important factor that influences Moroccan women's intention to buy colour cosmetics. Furthermore, Sa Sa International Holdings Limited; a leading cosmetic retailer and beauty services holding in Asia shows that married female are the largest 
segment of female consumers using colour cosmetics (www.firmstudio.com), 2018). This suggests that marital status could be very important in the explanation of the purchase pattern of colour cosmetic products.

\section{Research question}

What are the main factors affecting the purchase intention of Moroccan females toward the consumption of colour cosmetics?

\section{Hypotheses}

The following null hypotheses which are outlined in Figure 2 are developed:

$\mathrm{H}_{01}$ : There is no relationship between consumer motives and the intention to buy colour cosmetics.

$\log ($ intention $)=\beta 0+\beta 1$ sn_family $+\beta 2$ sn_Friends $+\beta 3$ Attitude $+\beta 4 \mathrm{PBC}+\varepsilon$

$\mathrm{H}_{02}$ : There is no relationship between intrinsic religiosity, extrinsic religiosity and the intention to buy colour cosmetics.

$$
\log (\text { intention })=\beta 0+\beta 1 \text { Intrinsic religiosity }+\beta 2 \text { Extrinsic Religiosity }+\varepsilon
$$

$\mathrm{H}_{03}$ : There is no relationship between TV channels and the intention to buy colour cosmetics. $\log ($ intention $)=\beta 0+\beta 12 \mathrm{M}+\beta 2 \mathrm{TF} 1+\beta 3$ RotanaRissala $+\beta 4$ AlOula $+\beta 5$ Rotana Clip + $\beta 6 \mathrm{MBC}$ Action $+\beta 7 \mathrm{MBC} 4+\beta 8 \mathrm{M} 6+\beta 9 \mathrm{Medi} 1+\beta 10 \mathrm{Ikraa}+\varepsilon$

$\mathrm{H}_{04}$ : There is no relationship between websites and the intention to buy colour cosmetics.

$\log$ (intention) $=\beta 0+\beta 1$ Facebook $+\beta 2$ Twitter $+\beta 3$ Fashion websites $+\beta 4$ streaming $($ YouTube $)+\beta 5$ Beauty websites $+\beta 6$ News $+\varepsilon$ 
$\mathrm{H}_{05}$ : There is no relationship between magazines and the intention to buy colour cosmetics. $\log ($ intention $)=\beta 0+\beta 1$ Femmes du Maroc $+\beta 2$ Maroc Premium $+\beta 3$ People $+\beta 4$ Telquel + $\beta 5$ Sayidaty $+\beta 6$ MarocHebdo $+\varepsilon$

$\mathrm{H}_{06}$ : There is no a relationship between demographic factors and the intention to buy colour cosmetics.

$\log ($ intention $)=\beta 0+\beta 1$ Age $+\beta 2$ Educational level $+\beta 3$ Income $+\beta 4$ Occupation $+\beta 5$ Perception of wealth as compared to neighbors $+\beta 6$ Household size $+\varepsilon$

Place Figure 2 about here

\section{Methodology}

The study uses a framework based on the theory of planned behavior to understand the consumer behaviors towards colour cosmetics in Morocco. In order to test these hypotheses, the positivism research paradigm is adopted using an ordered logistic regression model for testing the correlation and goodness of fit of the model. The hypothesized model is illustrated for identifying the relationship between variables.

Sampling Strategy:

An acceptable sample of the study is Moroccan females from all ages.Using the rule of thumb: The sample size in an ordered logistic regression is determined by: $N>50+8 \mathrm{k}$ (Lee and Green, 1991).

Where, $\mathrm{k}$ is the number of independent variables. 
In the study $\mathrm{k}=10^{1}$ Therefore, $\mathrm{N}>(50+8 * 10)$. The number of respondents should be greater than 130.

\section{Data collection:}

Survey:

The target population of the study is Moroccan female consumers of all ages as the use of color cosmetics is not restricted to a specific age interval (Euromonitor, 2013). The questionnaire measures the respondent's views on both intrinsic and extrinsic religiosity, and tests the respondents' use of media including their prefer choice (among TV, Magazines, and others) as well as the time spent with each media. It also included a demographics section to understand the relationship between the different profiling characteristics of the respondents and their purchasing intention. Internal consistency and reliability of the survey is tested for each section by assessing the value of the Cronbach's Alpha. A total of 650 questionnaire were distributed by trained pollsters using an intercept non-probabilistic sampling method in various urban locations all over Morocco. These are Ifrane and Azrou as small towns in the middle Atlas, while Fes and Meknes are middle size town, Tangier, Rabat and Casablanca are the administrative and economic capital respectively, and Tangier and Oujda being Morocco most important northern cities. Out of 650 questionnaire, 498 were returned. Since Morocco is a Muslim country, the questions related to religiosity correspond to Islam. The sampling is purposive probabilistic method, which helps a random selection of the sample based on the identified targeted characteristics of interest (Guarte and Barrios, 2006). The questionnaire was 
drafted in English and later translated into French using back translation techniques (Azjen, 2002). This translation was considered necessary because French is the most used language in Morocco after Arabic (El Khalfi, 2012). The questionnaire of the survey contains a section for each variable plus the demographics part. The survey is composed of 4 main sections which respectively measuring the variables related to the intention, attitude, subjective norm, perceived planned behavior, as well as both intrinsic and extrinsic religiosity. In addition, the survey also assesses the intensity of use of types of media: TV channels section, Internet sites, and the magazines. Finally, the survey includes a demographics section in order to profile the respondents in term of level of education, household size, income, occupation, perception of wealth compared to neighbors and age. Each variable was measured using standard Likert scales. For example, education was measured on a 7 pts Likert scale (1 corresponding to no education, to $7-\mathrm{PhD}$ ), age was measured on a 5 pts Likert scale with 1 corresponding to less than 20 , to 5 over 50 , Income was rated on a 8 pts Likert scale with 1 corresponding to less than 1500 Moroccan Dirham (MAD) per month (about USD150 in March 2018), to over 13,000 MAD.

Perception of Wealth was included in the demographics section although the goal was to test one aspect of the social norm theory. Wealth perception was measured on a 3 pts likert scale with the following question: "How do you perceive yourself compared to your neighbors?" (1 They are richer than us, 2. Similar, 3. We are richer than them).

Section 1 measures the intention to buy Colour Cosmetics: A five-point scale question ask respondents to rate their intention to use color cosmetics from 1 i.e Extremely Unlikely; to 5 i.e. Extremely Likely. The second section measures consumer attitude, subjective norms and perceived behavior control. Following (Venkatesh et al., 2003) attitude towards color cosmetics is measured by asking the respondents to answer following questions "For me, wearing make- 
up is?” Pleasant / Unpleasant, Respectable / Shameful, Satisfying / unsatisfying, Practical / unpractical on a five point likert scales . Concerning the Subjective norm, the questions measure the degree of approval among families, and friends. Concerning the perceived behavior control respondents have to rate their level of agreement with the question ": I have the final say in deciding to wear my make up" on a 5pts likert scale with 1 corresponding to "strongly disagree" and 5 "strongly agree". The third section measure the degree of both intrinsic and extrinsic religiosity. The construct of religiosity was included in the survey using nine questions. The scale followed the commitment inventory scale, which measures the commitment to religiosity (Worthington et al. 2003). Six questions were devoted to the extrinsic part while three were devoted to the intrinsic part. The last section measure respondents involvement with various media sources. Respondent were asked to rate the frequency of media usage (Magazine, TV, Internet) on a five point likert scale. A final section measure demographics such age, marital status, education, family size, location, occupation and income.

\section{Reliability of the Questionnaire}

Cronbach's alpha was used to determine the internal consistency of the survey. Cronbach's alpha was found to be 0.8099 for consumer motives while that of religiosity was found to be 0.8174 , and that of the media is 0.7735 .

\section{Presentation of Findings: profiling the respondents}

The descriptive statistics relating to profiling the respondents are given in Table 1

Place Table 1 about here

\section{Regression Analysis}

Ordered logistic regression 
The regression analysis is based on running an ordered logistic regression for each hypothesis; knowing that the independent and the dependent variables are categorical. The first step is to run a correlation test among the independent variables. If the correlation test signals a value higher than 0.6 , it means there is a correlation between the independent variables. For all hypotheses it was found that none of the independent variables were correlated.

\section{Testing TPB model:}

$\mathrm{H}_{01}$ : The model is found statistically significant at a 95\% level of confidence as Prob $>$ chi $2=0$ is $<0.05$. The significant independent variables are Attitude and perceived behavior control (PBC) and no significant relationship was found between sn_family; subjective norm of family; sn_friends; subjective norm of friends; and the intention to buy colour cosmetics.

Place Table 2 about here

- As shown in Table 2, the intention to buy color cosmetics increases by $42.9 \%$ as the importance of attitude increases by $1 \%$. Holding all the other independent variables constant, as the importance of perceived behavioral control increases by $1 \%$, the intention to buy color cosmetics increases by $30.9 \%$. Brant test provides evidence that the parallel regression analysis has not been violated.

\section{Religiosity and color cosmetic purchase intention:}

Color cosmetic purchase intention and religiosity are found to be correlated ( $\mathrm{p}$ value $=0.00$ ) Extrinsic religiosity was found to be negatively correlated to purchase intention. Hence more religious respondent are less likely to purchase color cosmetic and this by $14.8 \%$ (See Table 3 ).

Place Table 3 about here 
A Brant provided evidence that the parallel regression analysis has not been violated.

\section{Impact of Tv channels:}

The model is statistically significant at a $95 \%$ level of confidence, and hence TV channels viewing and the intention to buy color cosmetics are correlated. The channels having a significant impact on purchase intention are 2M, Rotana Clip, Ikraa, TF1, and MBC4 while no significant relationship was found between between RotanaRissala, M6, MBC Action, Eloula, Medil and the intention to buy colour cosmetics (See Table 4).

Place Table 4 about here

As respondents' time watching $2 \mathrm{M}$, RotanaClip, MBC4 increases by $1 \%$, the intention to buy color cosmetics increases by $30.8 \%, 48.7 \%$, and $20.6 \%$ repectively. On the other hand as as respondents' time watching Ikraa or TF1, increases by $1 \%$, the intention to buy color cosmetics increases by $48.7 \%$.decreases by $17.8 \%$ and $41.6 \%$ repectively. A Brant also confirms that the parallel regression analysis has not been violated.

\section{Websites:}

The model is statistically significant at a $95 \%$ level of confidence hence, there is a relationship between Websites and the intention to buy color cosmetics as shown in Table 5. The significant variables are Beauty websites and YouTube (streaming) and no significant relationship was found between Facebook, Twitter and the intention to buy colour cosmetics.

Place Table 5 about here 
A $1 \%$ usage of beauty websites or Youtube would lead to an increase in purchase intention by $36.6 \%$ and $27.6 \%$ repectively. Finally a brand test confirmed that the parallel regression analysis has not been violated.

\section{Impact of Magazine:}

Again The model is statistically significant. Maroc Hebdo and Maroc Premuim were found to be negatively correlated to the intention to buy colour cosmetics. A $1 \%$ increase in the respondents time spent on reading these magazine decrease the probability that a respondent will purchase color cosmetic by $28.4 \%$ and $43 \%$ respectively. (See Table 6 )

Place Table 6 about here

\section{The impact of demographic factors:}

The model is found statistically significant at a $95 \%$ level of confidence as the Prob $>$ chi2is found to be 0.00, which is less than 0.05. The significant independent variables are Age, Household Size, Income, Perceived Wealth as their P-values are less than 0.05 . There is no significant relationship between Occupation and the intention to buy colour cosmetics.

\section{Place Table 7 about here}

- As Table 7 shows, the significant variable are Age, Household Size, Income, Perceived Wealth. A $1 \%$ increase in these variable will increase the respondent intention to buy color cosmetic by $32.7 \%, 30.1 \%, 31.6 \%$ and $27.7 \%$ respectively.

\section{Goodness of fit}

Based on testing the sixth hypotheses running ordered regression model, we can conclude that there is a relationship between Intention and consumer motives, religiosity, TV channels, Websites, Magazines and demographics. Therefore, it is important to test goodness 
of fit by testing the variation of the dependent variable, which is intention and all other independent variables.

\section{The subsequent table illustrates the findings from STATA:}

\section{Place Table 8 about here}

Therefore, as shown in Table 8 we can conclude that there is a good fit between the data and the model according to the $\mathrm{R}^{\wedge} 2$ results:

- Based on Count $\mathrm{R}^{\wedge} 2,67.6 \%$ of the variation in the dependent variable, which is the intention to buy color cosmetics, can be explained by the independent variables.

- Based on McKelvey \& Zavoina’s R^2, 76.1\% of the variation in the dependent variable, which is the intention to buy color cosmetics, can be explained by the independent variables.

The model is statistically significant at a $95 \%$ level of confidence as the Prob $>$ chi2is found to be 0.00 , which is less than 0.05 . Hence, there is a relationship between the intention to buy color cosmetics and all the independent variables. Since the P-values are less than 0.05 , the significant independent variables of the model including all variables are Attitude, perceived behavior control (PBC), extrinsic religiosity, TF1 and Twitter

After running an ordered logistic regression, Brant test for the overall model was executed in order to determine whether there is any parallel regression assumption violation. As the $\mathrm{p}>\mathrm{chi} 2$ is bigger than 0.05 , it could be concluded that the non-significant test statistics provides evidence that the parallel regression analysis has not been violated.

Place Table 9 about here 
Table 9 sumarises the findings, shows the significant variables and indicates that all of the hypotheses are rejected.

\section{Discussion of the Findings}

Overall, this study examines the nexus of attitudes, religion, and the media in relation to Moroccan women's use of colour cosmetic products. The results show that there is a positive relationship between the intention to buy colour cosmetics and the women's age. This sounds logical as extant literature argues that women tends not to like looking old (Davies, 2006). As women get older, their use of color cosmetics becomes almost a necessity either to hide wrinkles or simply to look fresher. Therefore, for looking younger, beautiful, and attractive, a considerable number of Moroccan women wear make-up on a daily basis (Kumar, 2005). Furthermore, results show that the respondents' perceptions of wealth compared to their neighbors influence their intention to buy colour cosmetics. Perhaps, this could be explained by the fact that women's use of make-up to attract attention and as an indication that they can afford the products.

Moreover, results showed that there is a positive relationship between income and the intention to buy colour cosmetics. This lays considerable credence to the fact that Moroccan's women do not hesitate to spend money on their appearance if affordable (Euromonitor, 2013). Interestingly, finding shows that Moroccan females have a positive attitude towards colour cosmetics. As predicted in the framework proposed, the more positive the attitude towards a behavior, the more likely are consumers to buy the product associated with the behavior. Therefore, the result is consistent with previous studies such as those of Kim \& Chung (2011), Verbecke \&Vackier (2005), and Nash et al. (2006). 
It is also shown in this study that perceived behavior control (PBC) have a positive influence on consumer's intention to buy colour cosmetics. This confirms women's ambitions of independence of choice especially in the Moroccan context (Akbar, 2009). It aligns with the claim that Moroccan female consumers are no longer accepting to be controlled and manipulated (Euromonitor, 2013). The study also shows that the subjective norms for neither friends nor family is significant and does not influence the intention to buy colour cosmetics. This position contradicts the past view of the passive women who are unable to decide even when and where to wear make-up (Venkatesh et al., 2003; Boulanouar, 2010). So, Moroccan women are acting towards having more freedom in their choices and fight to get their rights (Sadiqi, 2008). This can be noticed by the huge denunciation of many laws such as limiting the age of marriage or obliging a victim to get married with the person who abused her.

Another interesting result is that religiosity has a very weak impact on Moroccan women's intention to buy colour cosmetics Upon reflection, although Morocco is a country with $99 \%$ of Muslim citizens (Central Intelligence agency, 2018), this paper suggests that Moroccan women do not give a great importance to religion in relation to these products. Intrinsic religiosity has no influence on Moroccan women's behavior towards buying colour cosmetics. This result might be explained by the fact that half of the respondents are between 21 and 30 years old who are typically noted as interested in looking gorgeous.. On the other hand, findings show that the extrinsic religiosity has a negative impact on the impact of buying colour cosmetics. So, as the extrinsic religiosity increases the intention to buy colour cosmetics decreases. Studies analyzing the relationship between religiosity and consumer behavior have shown that the link is sparse and conflicting (Syed, Rohani, and Badrul, 2011). This stance is confirmed in this current study. 
Concerning the media influence, these women were asked to rate TV channels that they most watched. The result is that Eloula and Medi1, Moroccan channels, have no significant impact on the intention to buy colour cosmetics even as Eloula is the first Moroccan channel. On the other hand, findings have proved that foreign channels such as Rotana and MBC (Middle East broadcasting modern channels) have a positive impact on consumer's intention to buy colour cosmetics. This result goes in line with recent studies that showed that Moroccan population prefers Middle East channels (Akbar, 2009). These results may be explained by the fact that foreign channels tend to highlight the importance of beauty and the use of colour cosmetics.

The results show that, the Arab channel, MBC and the French channel, TF1 are two channels that encourage Moroccan women to use cosmetics for taking care of their looks. While MBC highlights the importance of colors, TF1 boosts the importance of transparent make-up and more natural look. On the other hand, Moroccan channels do not provide a variety of programs that would attract mainly female consumers. For instance, Moroccan channels broadcast only one program in $2 \mathrm{M}$ called SABAHIYATE that discusses women issues. Meanwhile, a huge number of westernized advertisements attracts housewives and encourage them to watch foreign channels on a daily basis (Gregg, 2007). Consequently, based on the profiling description of the sample used, only $22.53 \%$ watch TV less than one hour a day. So, it could be argued that exposure to foreign and western channels which has been boosted by the availability of satellite channels, makes homemakers mainly influenced by the western and Middle East style of wearing make-up.

Meanwhile, concerning Magazines influence, the study showed that there is a negative relationship between the intention to buy colour cosmetics and Maroc Premuim magazine. The study also reveals that there is a positive influence of streaming mainly YouTube and the intention to buy colour cosmetics. This is explained by the huge number of videos on this 
platform that represents tutoring for women to wear different styles of make-up and on any occasion without being in need to pay a specialist.

\section{Managerial Implications}

Apart from the core theoretical contributions of this paper to the extant literature on selfconcept, women and beauty, it also has some noteworthy managerial implications. Essentially, the paper pinpoints the significant link of the media, attitudes, and religiosity. The implications revolve around the planning and implementation of integrated marketing communication for colour cosmetic products in the studied and similar contexts. So, it emphasizes appropriate choice of media and the message as of significant relevance in view of the religious positioning of these marketing communication channels. For instance, on this, it highlights the specific relevance of foreign marketing communication channels and tools as effective way for promoting these products. Besides, it also provides strategic direction about segmentation, targeting, and positioning for firms dealing in these products. For instance, the study pinpoints the middle-aged and old women age category as constituting good business opportunity to target as they are more encouraged to buy colour cosmetic products.

\section{Conclusion}

The study sheds light on consumer behavior towards colour cosmetics in Morocco.. In order to understand what affects the intention to buy colour cosmetics positively or negatively among Moroccan women, the study looked at the influence of media and religiosity following the theory of planned behavior as the theoretical framework. It suggests that Moroccan women crave their self-control in the consumption decisions in relation to colour cosmetic products as the perceived behavioral control has a positive influence on their consumption of these 
products. Although previous studies indicate that the role of religiosity in consumer decisions is unclear or ambiguous (Bachleda, Hamelin, and Benachour, 2012), it could be concluded from the study that Moroccan women are more influenced by media than religion. Religiosity has a very weak impact on their intention to buy colour cosmetics. Meanwhile, marketing communication channels such as Rotana and MBC have a positive impact on these consumers' intention to buy colour cosmetics as compared to the indigenous channels that are not particularly influential in this consumption context. Consequently, the exposure to western and other foreign channels make the women to be influenced by the western and Middle East styles of wearing make-up due to the availability of satellite channels. This cultural tensions constitute the core contribution of this study. It is interesting and noteworthy to indicate that old female consumers seem very keen to look young and fresh, which explains why they use these colour cosmetics. Conversely, younger girls who seem to have high self-confidence level and low income tend to seek more natural look and use transparent make-up. This is also linked to the findings of the study which emphasizes that there is a positive relationship between income and the intention to buy colour cosmetics among these women.

\section{Limitations and Further Researches}

Although this paper could be described as enlightening in relation to the subject matter it addresses, it also have some noteworthy limitations. Firstly, the finding might suffer from the representation bias of using a sample of only Moroccan women. Secondly, the respondents in the study might not have been totally honest in their answers. In some cases, people may hide their real opinions about some critical issues considered sensitive such as religiosity. However, to address this issue, the survey was made completely anonymous. Moreover, the diversity of 
the sample is limited with $55.97 \%$ of the respondents being between $21-30$ years old while $62.76 \%$ of them are single. Besides, even though the sample size is very large to run an ordered logistic regression analysis, it does not cover all Moroccan females’ population.

Meanwhile, as there is huge competition among different brands in the industry, a further research would be needed to analyze the consumer behavior towards different brands of colour cosmetics. It would be interesting to analyze how branding affect the intention to buy colour cosmetics in Morocco. Also, it could be theoretically and managerially illuminating to look into a larger perspective and study cosmetics in general not only colour cosmetics.

\section{References}

Ajzen, I. (1991)." The theory of planned behavior". Organizational Behavior Human_Decision Process, 50(12), 179-211.

Ajzen, I., (2002). Residual effects of past on later behavior: Habituation and reasoned action Perspectives. Personality and Social Psychology Review, 6(2), 107-122

Akbar, M. (2009). 'Cultural Invasion of Western Media and Muslim Societies. Retrieved from: http://www.aiou.edu.pk/gmj/CULTURAL\%20INVASION\%20OF\%20WESTERN\%20 MEDIA\%20AND\%20MUSLIM\%20SOCIETIES-4.asp

Al Abdulrazak, R.M. and Gbadamosi, A., (2017). Trust, religiosity, and relationship marketing: a conceptual overview of consumer brand loyalty. Society and Business Review, 12(3), 320-339. 
Allport, G. W and Ross, J.M. (1967). Personal religious orientation and prejudice. Journal of Personality and Social Psychology, 5 (4), 432-443.

Arbaoul, L. (2014), 'Morocco Ranks 4th of African Countries in Numbers of Facebook Users', $\begin{array}{llll}\text { Morocco } & \text { World } & 7^{\text {th }} & \text { February, }\end{array}$ 2014, https://www.moroccoworldnews.com/2014/02/121967/morocco-ranks-4th-of-africancountries-in-numbers-of-facebook-users/ (Accessed on $4^{\text {th }}$ March, 2018)

Arias, E. (2016). How does media influence social norms? a field experiment on the role of common knowledge. Working paper, 1-28

Armitage, C. and Conner, M. (2001)."Efficacy of the theory of planned behaviour: A meta- analytic review". British Journal of Social Psychology, 40(7), 471-499.

Arli, D., Arli, D., Pekerti, A., \& Pekerti, A. (2016). Investigating the influence of religion, ethical ideologies and generational cohorts toward consumer ethics: which one matters? Social Responsibility Journal, 12(4), 770-785.

Bachleda, C., Hamelin, N., \& Benachour, O. (2014). Does religiosity impact Moroccan Muslim women's clothing choice?. Journal of Islamic Marketing, 5(2), 210-226.

Banister, E.N. and Hogg, M.K. (2004), Negative symbolic consumption and consumers' drive for self-esteem: The case of the fashion industry. European Journal of Marketing, 38(7), 850-868.

Belk, R. W. (1998), 'Possessions and the extended self', Journal of Consumer Research, 12 (2), 139168

Belku, R. and Fiume, P. (2004), Religiosity and entrepreneurial behavior: an exploratory study, Entrepreneurship and Innovation, 5(3), 191-201.

Bessenoff, G. R. (2006). Can the media affect us? Social comparison, self-discrepancy, and the thin ideal. Psychology of women quarterly, 30(3), 239-251.

Boulanouar, A. (2010), “Myths and reality: Meaning in Moroccan Muslim women's dress”, doctoral dissertation, available at: http://otago.ourarchive.ac.nz/handle/10523/1748(accessed 20 July 2012). 
Brown, S. A., \& Venkatesh, V. (2005), Model of adoption of technology in households: A baseline model test and extension incorporating household life cycle. MIS quarterly, 29(3), 399-426.

Burchell, K., Rettie, R., \& Patel, K. (2013). Marketing social norms: social marketing and the 'social norm approach'. Journal of Consumer Behaviour, 12(1), 1-9.

Cash, T. F. (1988). “The psychology of cosmetics: a research biography”, Perceptual and Motor skills, 66(2): 455-60.

Cash, T.F. and Cash, D.W. (1982). "Women's use of cosmetics: psychosocial correlates and consequences”. International Journal of Cosmetic Science, 4(3), 1-13.

Casidy, R., Phau, I., \& Lwin, M. (2016), 'The role of religious leaders on digital piracy attitude and intention', Journal of Retailing and Consumer Services, 32, 244-252.

Central Intelligence Agency (2018), 'The word Fact Book: Africa: Morocco', ihttps://www.cia.gov/library/publications/resources/the-world-factbook/geos/mo.html

(Accessed on $4^{\text {th }}$ March, 2018)

Coulter, R. A., Price, L. L., and Feick, L., (2003).Rethinking the origins of involvement and brand commitment: insights from post-socialist Central Europe. Journal of Consumer Research, 30(2): 151-169.

Craik, J. (1993), The Face of Fashion: Cultural studies in Fashion: London: .Routledge

Crespo, A. H., and Rodríguez, I. R., (2008).Explaining B2C e-commerce acceptance: An integrative model based on the framework by Gatignon and Robertson. Interacting with Computers, 20(2): 212-224.

Davies, B., (2006), Color's emerging strategy urges trade up. Global cosmetic industry, 174(5): 48-50. Decision Process, 50(12), 179-211.

Delener, N. (1994)."Religious contrasts in consumer decision behaviour patterns: Their dimensions and marketing implications”. European Journal of Marketing, 28(5), 36-53.

Delener, N. (1990). The effects of religious factors on perceived risk in durable goods purchase decision. Journal of Consumer Marketing, 7(3), 27-38. 
El Khalfi, M. (2012). La langue française serait-elle en danger dans les medias marocains?. Retrieved from http://www.welovebuzz.com/la-langue-francaise-serait-elle-en-danger-dans-les-medias$\underline{\text { marocains/ }}$

Elliott, R. (1997), 'Existential consumption and irrational desire', European Journal of Marketing, 31 (3), 285-296

Essoo, N. and Dibb, S. (2004). "Religious influences on shopping behaviour: An exploratory Study". Journal of Marketing Management, 20(7/8), 683-712.

Euromonitor (2013). Consumers LifeStyles in Morocco. Available at: http://www.euromonitor.com/consumer-lifestyles-in-morocco/report

Fam, K., S. Waller, D.S. and Erdogan, B., Z. (2004), 'The influence of religion on attitudes towards the advertising of controversial products'. European Journal of Marketing, 38(5/6), pp.537-555.

Femmes du Maroc (2012). Retrievedfrom: http://www.femmesdumaroc.com/

Fishbein, M. and Ajzen, I. (2010). Predicting and Changing Behaviour: The Reasoned Action Approach. Psychology Press, New York.

Gbadamosi, A. (2012). 'Acculturation: An exploratory study of clothing consumption among Black African women in London (UK)'. Journal of Fashion Marketing and Management: An International Journal, 16(1), 5-20

Gbadamosi, A. (2015). 'Brand personification and symbolic consumption among ethnic minority teenage consumers: An empirical study'. Journal of Brand Management, 22(9), 737-754.

Gbadamosi, A. (2018), 'Women Entrepreneurship, Religiosity, and Value-co-creation with Ethnic Consumers: Revisiting the Paradox', Journal of Strategic Marketing, DOI: 10.1080/0965254X.2017.1344293 (in press)

Gray, K. and Amine, L. (2002), "Doing business in Morocco". Thunderbird International Business Review, 44(3), 379-398.

Gregg, G. (2007).Culture and Identity in Muslim society. Oxford University Press

Grubb, E. L., \& Grathwohl, H. L. (1967). Consumer self-concept, symbolism and market behavior: A theoretical approach. The Journal of Marketing, 31(4), 22-27. 
Guthrie, F. M., Kim, H-S., and Jung, J., (2008).The effects of facial image and cosmetic usage on perceptions of brand personality. Journal of Fashion Marketing and Management, 12(2): 164181.

Haines, M. P. (1996). A Social Norms Approach to Preventing Binge Drinking at Colleges and Universities.

Ham, M., Jeger, M., \& Frajman Ivković, A. (2015). The role of subjective norms in forming the intention to purchase green food. Economic research-Ekonomska istraživanja, 28(1), 738-748.

Hessini, L. 1994. Wearing the hijab in contemporary Morocco: Choice and identity.In Reconstructing gender in the Middle East: Tradition, identity, and power, ed. F. M. Gocek and S. Balaghi. New York: Columbia University Press

Kim, H. Y., and Chung, J. E., (2011).Consumer purchase intention for organic personal care products. Journal of Consumer Marketing, 28(1): 40-47.

Kotler, P. and Armstrong, G. (2018), 'Principles of Marketing' 17 th $^{\text {th }}$ edn, Harlow: Pearson Education Limited

Kotwal, N., Gupta, N., and Devi, A. (2008). "Impact of T.V Advertisements on Buying Pattern of Adolescent Girls", Journal of Social Sciences, 16 (1), pp. 51-55

Kumar, S., (2005), Exploratory analysis of global cosmetic industry: major players, technology and market trends.Technovation, 25(11), 1263-1272

Kulsiri, P., (2012) Self-concept, locus of control, media exposure, and behavior of youth toward luxury products purchase. Journal of Business \& Economics Research (Online), 10(1), p.11-18

LaBarbera, P. (1987). Consumer behavior and born again Christianity. In Sheth, J. N. and Hirschman, E. (eds.), Research in Consumer Behavior, 2(1), 193-222

Le Journal Hebdo. (2012). $2 \mathrm{M}$ reste en pôle position au Maroc . Retreived from: http://www.yabiladi.com/forum/reste-pole-position-maroc-2-1988638.html

Lee, C. \& Green, R. T. (1991).Cross-cultural examination of the Fishbeinbehavioral Intentions model.Journal of International Business Studies, 22(17), 289-305. 
Liao, S. H., Hsieh, C. L., and Huang, S. P., (2008). Mining product maps for new product development. Expert Systems with Applications, 34(1), 50-62.

Marcoux, D., (2000). Appearance, cosmetics, and body art in adolescents. Dermatologic Clinics, $18(4,: 667-673$.

Nash, R., Fieldman, G., Hussey, T., Lévêque, J. L., \& Pineau, P. (2006). Cosmetics: They influence more than Caucasian female facial attractiveness, Journal of Applied Social Psychology, 36(2), 493-504.

Nikdavoodi, J., (2013), The Impact of Attitude, Subjective Norm and Consumer Innovativeness on Cosmetic Buying Behavior, Master Thesis, School of Economics and Management, Lund University.

O'Shaughnessy J. \& O'Shaughnessy, N. J. (2002), 'Marketing, the consumer society and hedonism, European Journal of Marketing, 36 (5/6), 524-547.

Perloff, R. M. (2014), Social media effects on young women's body image concerns: Theoretical perspectives and an agenda for research. Sex Roles, 71(11-12), 363-377.

Peterson, L. R. \& Roy. A. (1985). Religiosity, anxiety and meaning and purpose: Religions consequences for psychological well-being. Journal of Health and Social Behavior. 30(1): 92104

Pinhas, L., Toner, B. B., Ali, A., Garfinkel, P. E., \& Stuckless, N. (1999). The effects of the ideal of female beauty on mood and body satisfaction. International Journal of Eating Disorders, 25(2), 223-226.

Rucker, D. D., Dubois, D., \& Galinsky, A. D. (2011). Generous paupers and stingy princes: Power drives consumer spending on self versus others. Journal of Consumer Research, 37(6), 10151029.

Sadiqi, F. (2008), "The central role of the family law in the Moroccan feminist movement" British Journal of Middle Eastern Studies, 35(3), 325-337. 
Scott, J. W. (2007), 'Gender as a useful category of historical analysis: A Reader'. In Parker, R. and Aggleton, P. (Eds.) In Culture, society and sexuality, (pp. 77-97). Routledge.

Siguaw, J. and Simpson, P. (1997)."Effects of religiousness on Sunday shopping and out Shopping behaviours: A study of shopper attitudes and behaviours in the American South". International Review of Retail, Distribution and Consumer Research, 7(1), 23-40.

Souiden, N., and Diagne, M., (2009). Canadian and French men's consumption of cosmetics: a comparison of their attitudes and motivations. Journal of Consumer Marketing, 26(2), 97-109.

Sukato, N., and Elsey, B., (2009). A model of male consumer behaviour in buying skin care products in Thailand. ABAC Journal, 29(1), 39-52.

Syed,A., Rohani, M. and Badrul, H. (2011). "Is religiosity an important determinant on Muslim consumer behaviour in Malaysia?". Journal of Islamic Marketing, 2(1), 83 - 96.

Vanessa, A-I., Hartmann, P., Diehl, S., and Terlutter R., (2010).Women satisfaction with cosmetic brands: The role of dissatisfaction and hedonic brand benefits. African Journal of Business Management, 5(3), 792-802.

Veer, E. and Shankar, A. (2011), Forgive me, Father, for I did not give full justification for my sins: how religious consumers justify the acquisition of material wealth, Journal of Marketing Management, 27 (5-6), 547-560.

Venkatesh, V., Morris, M. G., Davis, F. D., and Davis, G. B., (2003).User Acceptance of Information Technology: Toward a Unified View. MIS Quarterly, 27(3), 425-478.

Verbeke, W., and Vackier, I., (2005).Individual determinants of fish consumption: Application of the theory of planned behaviour. Appetite, 44(1), 67-82.

Worthington, E.L., Jr., Wade, N.G., Hight, TL., McCullough, M.E., Berry, J.T., Ripley, J.S., Berry, J.W., Schmitt, M.M. and Bursley, K.H. (2003). "The religious commitment inventory-10: Development, refinement, and validation of a brief scale for research and counseling”, Journal of counseling psychology, 50(1), 84-96. 
(www.firmstudio.com), W. (2018). Sa Sa - Annual and Interim Reports. [online] Corp.sasa.com.

Available at: http://corp.sasa.com/en/investor-relations/annual-and-interim-report/2013-14/

[Accessed 8 Jun. 2018].

Table 1: Profiling the respondents

\begin{tabular}{|c|c|c|}
\hline & Issue in focus & Summary of Findings \\
\hline 1 & $\begin{array}{l}\text { Intention to } \\
\text { buy color } \\
\text { cosmetics }\end{array}$ & $\begin{array}{l}\text { From the survey result, we can deduce that } 46.12 \% \text { of } \\
\text { respondents have the intention to buy color cosmetics very } \\
\text { often, while those who buy them often constitutes } 14.47 \% \text { but } \\
\text { those that indicate that they will buy them sometimes are } \\
\text { approximately } 9.644 \% \text {. Conversely, } 23.69 \% \text { of the respondents } \\
\text { do not intend to buy color cosmetics while those who indicated } \\
\text { that they rarely buy them are only } 6.08 \%\end{array}$ \\
\hline 2 & $\begin{array}{l}\text { Amount of time } \\
\text { spent watching } \\
\text { TV per day }\end{array}$ & $\begin{array}{l}\text { The amount of time respondents spend watching TV is very } \\
\text { significant. The figure below show that } 39.06 \% \text { of respondents } \\
\text { watch TV more than } 3 \text { hours a day while only } 22.53 \% \text { watch } \\
\text { TV less than one hour a day. Moreover, those who watch TV } \\
\text { between } 1 \text { and } 3 \text { hours a day constitutes } 38.41\end{array}$ \\
\hline 3 & $\begin{array}{lr}\text { Number } & \text { of } \\
\text { hours } & \text { spent } \\
\text { using } & \text { Internet } \\
\text { per day } & \end{array}$ & $\begin{array}{l}\text { The result shows the amount of time that respondents spend on } \\
\text { Internet per day. } 39.74 \% \text { use Internet between } 1 \text { hour and } 3 \\
\text { hours while } 33.55 \% \text { use it more than } 3 \text { hours, and those who use } \\
\text { it for between } 1 \text { and } 3 \text { hours are almost } 40 \%(39.74 \%) \text {. }\end{array}$ \\
\hline 4 & $\begin{array}{lr}\text { Frequency } & \text { of } \\
\text { reading } & a \\
\text { magazine per } \\
\text { week }\end{array}$ & $\begin{array}{l}\text { More than half of respondents }(71.28 \%) \text { do not read any } \\
\text { magazine per week while } 25.16 \% \text { read a magazine one to three } \\
\text { times a week, and those who read a magazine more than three } \\
\text { times a week constitute only } 3.564 \% \text {. }\end{array}$ \\
\hline 5 & Age & $\begin{array}{l}55.97 \% \text { of the respondents are between } 21 \text { and } 30 \text { years old. } \\
\text { While the respondents over } 50 \text { years old are underrepresented. } \\
\text { Furthermore, } 31.24 \% \text { of the respondents are less than } 20 \text { years } \\
\text { old }\end{array}$ \\
\hline 6 & Marital Status & $\begin{array}{l}\text { The majority of the respondents are single. } 29.71 \% \text { of the } \\
\text { respondents are married while } 6.49 \% \text { are divorced. }\end{array}$ \\
\hline 7 & Education & $\begin{array}{l}1.677 \% \text { of the respondents have not attended school, } 0.8 \% \text { have } \\
\text { finished primar school, } 5.2 \% \text { have attended a secondary school, }\end{array}$ \\
\hline
\end{tabular}




\begin{tabular}{|c|c|c|}
\hline & & $\begin{array}{l}46.7 \% \text { have attended college, } 41.7 \% \text { have a bachelor degree, } \\
3.35 \% \text { have a master degree, } 1.6 \% \text { have a } \mathrm{PhD} \text {. }\end{array}$ \\
\hline 8 & Occupation & $\begin{array}{l}1.2 \% \text { are retired, } 30.53 \% \text { are student, } 21.2 \% \text { are employed, } 24.2 \\
\text { are in liberal profession, } 21.2 \% \text { are looking for a job and } 20.21 \% \\
\text { of the respondents are housewives }\end{array}$ \\
\hline 9 & Income & $\begin{array}{l}54.2 \% \text { earn less than } 15000 \text { MAD per month, } 33.2 \% \text { between } \\
1501 \text { and } 3000 \text { MAD per month, } 9.2 \% \text { earn between } 3001 \text { and } \\
5000 \text { MAD, } 2.9 \% \text { between } 5001 \text { and } 7000 \text { MAD , } 0.4 \text { earn } \\
\text { above } 7000 \text { MAD }\end{array}$ \\
\hline 10 & Family Size & $\begin{array}{l}50.6 \% \text { have a household composed of } 6 \text { or more people, } 38.6 \% \\
\text { between } 3 \text { to } 5 \text { member and } 11.34 \% \text { are household of } 2 \text { members } \\
\text { or less. }\end{array}$ \\
\hline 11 & $\begin{array}{l}\text { Geographical } \\
\text { Location }\end{array}$ & $\begin{array}{l}28.6 \% \text { are from Meknes, } 24.9 \% \text { from Fez, } 8.5 \% \text { are from Ifrane, } \\
5.0 \% \text { from Tanger, } 5.0 \% \text { from Casablanca, } 3.3 \% \text { from Mrirt, } \\
2.5 \% \text { from Midelt, } 0.6 \% \text { from Khenifra and } 0.4 \% \text { from Oujda, }\end{array}$ \\
\hline
\end{tabular}

Table2: Consumer motives and the intention to buy color cosmetics

\begin{tabular}{|l|l|l|l|l|}
\hline $\begin{array}{l}\text { Intention to buy } \\
\text { Color Cosmetics } \\
(\mathbf{N = 4 7 7 )}\end{array}$ & $\mathbf{B}$ & $\mathbf{Z}$ & $\mathbf{P}>\mathbf{Z}$ & $\%$ \\
\hline Attitude & 0.3572 & 13,16 & 0.000 & 42.9 \\
\hline sn_family & 0.0141 & 0.21 & 0.830 & 1.4 \\
\hline sn_Friends & -0.0531 & -0.69 & 0.488 & -5.2 \\
\hline PBC & 0.6380 & 6.60 & 0.000 & 30.9 \\
\hline
\end{tabular}


Table3: Religiosity and the intention to buy color cosmetics

\begin{tabular}{|l|l|l|l|l|}
\hline $\begin{array}{l}\text { Intention to buy } \\
\text { Color Cosmetics } \\
(\mathbf{N = 4 7 7 )}\end{array}$ & B & Z-value & P-value & $\%$ \\
\hline Intr_Religiosity & -0.0566 & -1.91 & 0.056 & -5.5 \\
\hline Extr_Religiosity & -0.1598 & -4.51 & 0.000 & -14.8 \\
\hline
\end{tabular}


Table 4: TV Channels and the Intention to buy colour cosmetics

\begin{tabular}{|l|l|l|l|l|}
\hline $\begin{array}{l}\text { Intention to buy } \\
\text { Color Cosmetics } \\
\text { (N=462) }\end{array}$ & $\mathbf{B}$ & $\mathbf{Z}$ & $\mathbf{P}>\mathbf{Z}$ & $\%$ \\
\hline $2 \mathrm{M}$ & 0.2686 & 2.7 & 0.007 & 30.8 \\
\hline ELoula & -0.1092 & -1.13 & 0.285 & -10.3 \\
\hline Medi1 & 0.0212 & 0.22 & 0.829 & 2.1 \\
\hline RotanaClip & 0.3967 & 4.51 & 0.000 & 48.7 \\
\hline RoanaRissala & -0.1242 & -1.52 & 0.128 & -11.7 \\
\hline Ikraa & -0.1958 & -2.49 & 0.013 & -17.8 \\
\hline TF1 & -0.5372 & -4.5 & 0.000 & -41.6 \\
\hline M6 & -0.0463 & -0.48 & 0.633 & -4.5 \\
\hline Mbc4 & 0.1877 & 2.33 & 0.020 & 20.6 \\
\hline MBCAction & -0.0291 & -0.34 & 0.732 & -2.9 \\
\hline
\end{tabular}


Table 5: Websites and the intention to buy color cosmetics

\begin{tabular}{|c|c|c|c|c|}
\hline $\begin{array}{lcr}\text { Intention } & \text { to } & \text { buy } \\
\text { Color } & \text { Cosmetics } \\
(N=474) & \\
\end{array}$ & B & $\mathbf{Z}$ & $\mathbf{P}>\mathbf{Z}$ & $\%$ \\
\hline Facebook & -0.0501 & -0.747 & 0.455 & -4.9 \\
\hline Twitter & 0.0141 & 0.458 & 0.647 & 3.2 \\
\hline Beauty_websites & -0.0531 & 4.075 & 0.000 & 36.6 \\
\hline Streaming(YouTube) & 0.6380 & 3.367 & 0.001 & 27.6 \\
\hline
\end{tabular}


Table 6: Magazines and the Intention to buy colour cosmetics

\begin{tabular}{|l|l|l|l|l|}
\hline $\begin{array}{l}\text { Intention to buy } \\
\text { luxury goods } \\
\text { N=477) }\end{array}$ & B & $\mathbf{Z}$ & P-value & $\%$ \\
\hline Sayidaty & 0.1422 & 1.561 & 0.118 & 15.3 \\
\hline Femmes du Maroc & 0.2496 & 1.876 & 0.061 & 28.4 \\
\hline Telquel & 0.2024 & 1.162 & 0.245 & 22.4 \\
\hline Maroc Premium & -0.3361 & -2.095 & 0.036 & -28.4 \\
\hline MarocHebdo & -0.5628 & -2.378 & 0.017 & -43.0 \\
\hline
\end{tabular}


Table 7: Demographic factors and intention to buy Colour Cosmetics

\begin{tabular}{|c|c|c|c|c|}
\hline $\begin{array}{|lr|}\text { Intention } & \text { to buy } \\
\text { luxury } & \text { goods } \\
(\mathrm{N}=465) & \\
\end{array}$ & B & $\mathbf{Z}$ & $\mathbf{P}>\mathbf{Z}$ & $\%$ \\
\hline Education & 0.0757 & 0.668 & 0.504 & 7.9 \\
\hline Household size & 0.2748 & 2.064 & 0.039 & 31.6 \\
\hline Income & 0.2632 & 2.114 & 0.034 & 30.1 \\
\hline Occupation & 0.037 & 0.286 & 0.775 & 3.8 \\
\hline $\begin{array}{l}\text { Perception } \\
\text { wealth } \\
\text { compared } \\
\text { neighbors }\end{array}$ & 0.244 & 2.181 & 0.029 & 27.7 \\
\hline Age & 0.2831 & 6.598 & 0.000 & 32.7 \\
\hline
\end{tabular}


Table 8: Goodness of fit for the overall model

\begin{tabular}{|l|l|}
\hline Count $R 2$ & 0.676 \\
\hline McKelvey\&Zavoina's $R^{\wedge} 2$ & 0.761 \\
\hline ML (COX-Snell) $R^{\wedge} 2$ & 0.652 \\
\hline Nagelkerke R2 & 0.699 \\
\hline
\end{tabular}


Figure 1: Framework of applying the theory of planned behavior for the intention to buy colour cosmetics

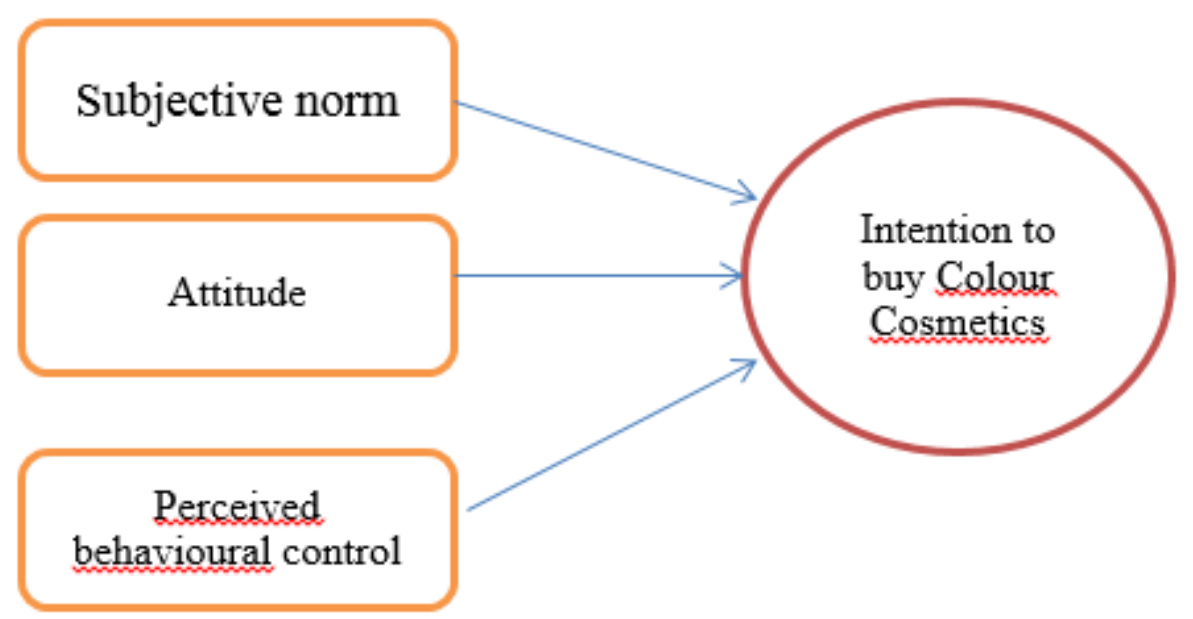

Source: Fishbein and Ajzen (2010). 
Figure 2: Illustration of the hypothesized model

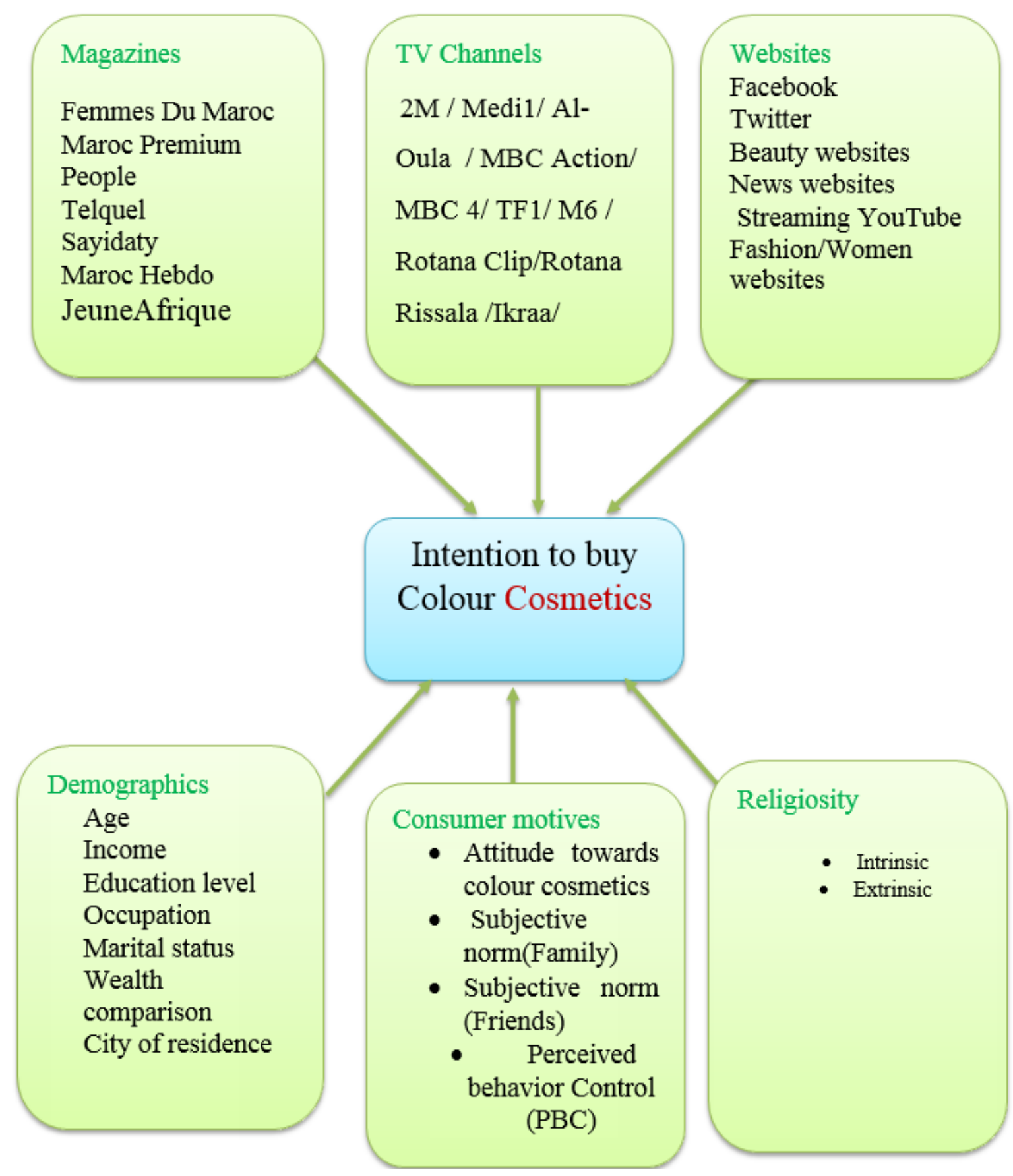


